\title{
PELAKSANAAN PENILAIAN AUTENTIK KURIKULUM 2013 PADA PEMBELAJARAN TEMATIK TEMA SUMBER ENERGI KELAS III DI MI NEGERI 1 YOGYAKARTA
}

\author{
Wina Calista \\ e-mail: winacalista21@gmail.com \\ Pascasarjana Fakultas Ilmu Tarbiyah dan Keguruan \\ Universitas Islam Negeri Sunan Kalijaga Yogyakarta
}

\begin{abstract}
Abstrak
Tujuan penelitian ini untuk mendeskripsikan pelaksanaan penilaian autentik pada kurikulum 2013 pada pembelajaran tematik pada tema sumber energi kelas III di MI Negeri 1 Yogyakarta. Berdasarkan hasil penelitian dapat disimpulkan bahwa : pelaksanaan penilaian autentik kurikulum 2013 pada siswa kelas IIIC di MI Negeri 1 Yogyakarta belum secara optimal diterapkan oleh guru. Pada kurikulum 2013 penilaian mencakup ranah afektif, kognitif dan psikomotor, tetapi pada proses pembelajaran ketiga penilaian tersebut belum secara optimal diterapkan oleh guru dalam pembelajaran. Dalam hal ini guru hanya menerapkan penilaian hanya pada ranah kognitif atau pengetahuan dalam bentuk tes lisan dan tes tertulis. Pada penilaian ranah afektif dan psikomotor guru tidak melakukan penilaian dan juga tidak adanya intrumen penilaian yang menjadi acuan guru pada saat proses pembelajaran. Dari hasil wawancara melatarbelakangi guru tidak melakukan penilaian disebabkan karena guru yang sudah memiliki pengalaman mengajar dikelas III selama sepuluh tahun sehingga guru sudah memahami karakteristik siswa kelas III SD/MI. Mengacu pada Permendikbud No 66 tahun 2013 tentang standar penilaian pendidikan bahwa penilaian autentik kurikulum 2013 ranah afektif, kognitif dan psikomotor harus diterapkan oleh guru yang dimulai pada awal pembelajaran, proses pembelajaran dan akhir proses pembelajaran.
\end{abstract}

Kata kunci: Pelaksanaan, Penilaian Autentik 2013, Pembelajaran Tematik

\section{PENDAHULUAN}

Kurikulum memegang peran penting dalam pendidikan, sebab kurikulum berkaitan langsung dengan arah, isi dan proses pendidikan. Unsur-unsur yang terdapat dalam tubuh kurikulum, yang utama adalah tujuan, isi atau materi, proses penyampaian materi, serta evaluasi. (Sukmadinata, 2012). Salah satu tuntutan pada perubahan kurikulum 2006 atau KSTP ke kurikulum 2013 adalah penilaian autentik. Kurikulum 2013 menganggap bahwa penilaian autentik merupakan penilaian yang tepat untuk menilai hasil belajar siswa. Hal ini senada dengan yang tertuang didalam Permendikbud No. 104 tahun 2014 pasal 2 ayat 2 yang menyebutkan bahwa penilaian autentik merupakan pendekatan utama dalam penilaian hasil belajar

MODELING: Jurnal Program Studi PGMI

Volume 6, Nomor 2, September 2019; p-ISSN: 2442-3661; e-ISSN: 2477-667X, 196-203 
peserta didik oleh pendidik. Sebenarnya pada kurikulum 2006 sudah mengandung penilaian autentik, akan tetapi pada implementasi belum secara maksimal dilakukan.

Penilaian pada kurikulum 2013 yang mengacu pada Permendikbud No 66 tahun 2013 tentang Standar Penilaian Pendidikan. Standar penilaian pendidikan adalah suatu kriteria yang berkaitan dengan mekanisme, prosedur dan instrument penilaian hasil belajar peserta didik. Pada penilaian autentik kurikulum 2013 mencakup ranah sikap, keterampilan dan pengetahuan. Penilaian ini dilakukan tidak hanya diakhir pembelajaran saja, akan tetapi dimulai pada awal pembelajaran, proses atau pada saat pembelajaran berlangsung hingga akhir proses belajar mengajar. Sebagaimana menurut (Hosman, 2013) bahwa penilaian autentik yang mencakup ranah afektif, kognitif dan psikomotor yang dilakukan oleh guru harus secara sesuai dengan keadaan yang sedang dialami pada saat proses pembelajaran dikelas. Berkaitan dengan hal tersebut penilaian pembelajaran di SD/MI dan jenjang pendidikan dasar dan menengah lainnya telah bergeser ke era model penilaian baru yang lebih representative dan mampu menggambarkan kemampuan yang senyatanya yang berhasil dikuasai oleh siswa karena sebelum adanya kurikulum 2013 penilaian yan dilakukan oleh guru masih bersifat tes objektif maupun tes lisan.

Penilaian autentik memiliki relevansi kuat terhadap pendekatan ilmiah dalam pembelajaran sesuai dengan tuntutan kurikulum 2013. Penilaian tersebut mampu menggambarkan peningkatan hasil belajar peserta didik, baik dalam rangka mengobservasi, menalar, mencoba, membangun jaringan dan lain-lain. Penilaian autentik cenderung fokus pada tugas-tugas kompleks atau kontekstual, memungkinkan peserta didik untuk menunjukkan kompetensi mereka dalam pengaturan yang lebih autentik. Penilaian autentik sangat relevan dengan pendekatan tematik terpadu dalam pembelajaran, khususnya jenjang SD/MI atau untuk mata pelajaran yang sesuai. (Majid, 2014). Selain itu penilaian autentik pada jenjang SD/MI juga harus lebih menekankan pada kompetensi sikap. Hal ini karena pada jenjang SD/MI penekanan kompetensi sikap harus benar-benar menjadi penekanan dan perhatian, sehingga ketika peserta didik melanjutkan ke jenjang pendidikan yang lebih tinggi sudah memiliki fondasi sikap yang kuat dan dijenjang yang lebih tinggi tinggal memperdalam kompetensi pengetahuan dan keterampilannya.

Untuk itu agar implementasi penilaian autentik dalam pembelajaran di sekolah terutama jenjang SD/MI guru harus menyiapkan hal-hal yang dibutuhkan dalam penerapan penilaian autentik, salah satunya adalam intrumen penilaian. Karena didalam kurikulum 2013 terdapat tiga ranah yang harus dinilai oleh guru, sehingga guru dituntut untuk membuat instrument yang bervariasi yang mencakup ranah afektif, kognitif dan psikomotor.

Dari hasil observasi bahwa guru tidak menggunakan instrumen penilaian untuk ranah afektif dan psikomotor. Hal itu tidak terlihat ketika pembelajaran dikelas guru hanya mencatat nilai-nilai siswa yang berhasil dalam menjawab pertanyaan secara lisan dan tertulis dari guru. Berdasarkan uraian permasalahan di atas untuk mengetahui secara mendalam tentang penerapan penilaian autentik, dalam artikel ini 
akan dibahas tentang Pelaksanaan Penilaian Autentik Pada Kurikulum 2013 Pada Pembelajaran Tematik Pada Tema Sumber Energi Kelas III di MI Negeri 1 Yogyakarta

\section{METODE PENELITIAN}

Jenis penelitian yang dilakukan adalah penelitian kualitatif. Penelitian ini bersifat deskriptif kualitatif yang merupakan penelitian yang menghasilkan data deskriptif berupa kata-kata tertulis atau lisan berdasarkan penelitian yang dilakukan dilapangan secara intensif, terperinci, dan mendalam. Subjek dalam penelitian ini adalah guru kelas IIIC dan seluruh siswa IIIC. Teknik pengumpulan data dan informasi peneliti menggunakan teknik observasi, wawancara dan dokumentasi. Adapun analisis data yang dilakukan yaitu meliputi: reduksi data, penyajian data, dan penarikan kesimpulan. Sedangkan teknik keabsahan data menggunakan ketekunan pengamatan dan trianggulasi. (Sugiyono, 2014)

\section{HASIL PENELITIAN DAN PEMBAHASAN Hasil Penelitian}

Penelitian ini bertujuan untuk mendeskripsikan penerapan penilaian autentik pada kurikulum 2013 pada pembelajaran tematik pada tema sumber energi kelas III di MI Negeri 1 Yogyakarta. Penelitian ini dilakukan dengan mengumpulkan data dengan cara melakukan observasi di kelas yang dijadikan sebagai subjek penelitian, yaitu kelas IIIC dengan jumlah siswa sebanyak 29 siswa dan dalam penelitian ini guru tematik kelas IIIC merupakan sumber informasi utama.

Berdasarkan hasil observasi awal dikelas diketahui bahwa pola pembelajaran yang diterapkan oleh guru dikelas IIIC yaitu sistem belajar secara berkelompok. Dari jumlah siswa sebanyak 29 dibagi menjadi tiga kelompok, yang masing-masing kelompok sebanyak sembilan atau sepuluh siswa. Masing-masing kelompok tersebut memiliki nama kelompok masing-masing yang diambil dari nama buah, yaitu Naga, Jeruk dan Chery. Kelas IIIC merupakan kelas yang tergolong aktif dalam pembelajaran, hal ini terlihat siswa selalu merespon dengan baik pada saat guru memberikan pertanyaan kepada siswa. Pada proses pelaksanaan pembelajaran dikelas, guru mengawali pembelajaran dengan bernyanyi, hal ini bertujuan untuk memingkatkan motivasi belajar siswa sebelum memulai pembelajaran. Dari masingmasing kelompok, siswa diminta oleh guru untuk menampilkan lagu yel-yel yang menjadi ciri khas dari masing-masing kelompok.

Penjelasan hasil observasi awal tersebut memiliki makna bahwa dengan adanya sistem pembelajaran secara berkelompok maka secara tidak langsung guru melatih siswa untuk dapat berpatisipasi dengan baik dengan sesama teman, melatih siswa untuk menghargai dan menerima pendapat orang lain, serta juga dapat menjalin kebersamaan yang baik. Hal ini sejalan dengan pendapat (Harsanto, 2007) bahwa dengan penerapan sistem belajar secara berkelompok, maka salah satunya dapat menumbuhkan keterampilan dasar yang dibutuhkan dalam hidup. Keterampilan tersebut antara lain sikap mendengarkan, menerima pandangan orang lain, 
berkomunikasi secara efektif, menyelesaikan konflik, dan bekerja sama untuk mencapai tujuan bersama.

Selain penerapan sistem belajar secara berkelompok, kreatifitas yang di tanamkan oleh guru juga dapat melatih siswa dalam mengembangkan ide-ide nya Hal ini terlihat pada saat siswa menentukan nama kelompok masing-masing berdasarkan tema yang ditentukan oleh guru dan juga siswa yang dilatih untuk menciptakan yelyel kelompok yang kemudian siswa dilatih untuk memiliki rasa percaya diri untuk menampilkan yel-yel lagu tersebut didepan kelas. Rasa percaya diri yang dimiliki siswa tersebut tidak terlepas dari adanya motivasi belajar yang guru tanamkan dalam pembelajaran. Sebagaimana diketahui bahwa salah satu indikator dalam meningkatkan motivasi belajar adalah adanya kegiatan belajar yang menarik (Uno, Hamzah B, 2012).

Ditinjau dari kreatifitas belajar dan motivasi belajar yang ditanamkan oleh guru pada pembelajaran dikelas IIIC tergolong sudah cukup baik. Akan tetapi pada implementasi hasil belajar yang dilakukan oleh guru belum secara keseluruh dapat dikategorikan baik. Hal ini karena guru belum sepenuhnya menerapkan penilaian autentik pada kurikulum 2013 yang meliputi penilaian ranah afektif, kognitif dan psikomotor. Dari proses pembelajaran, setelah guru menjelaskan materi, guru memberikan tes secara lisan kepada siswa dan tes tertulis secara berkelompok. Dalam ini dilakukan oleh guru dari awal hingga akhir pembelajaran. Dari hasil observasi tidak terlihat guru melakukan penilaian untuk ranah afektif dan psikomotor. Hal ini dibuktikan dengan tidak adanya instrument yang digunakan oleh guru pada saat pembelajaran. Dari hasil wawancara dengan guru tematik dikelas IIIC bahwa guru sudah memiliki pengalaman mengajar yang sudah sepuluh tahun dikelas III MI. Sehingga sudah memahami karakteristik siswa kelas III. Dari hasil wawancara tersebut dapat disimpulkan bahwa yang melatarbelakangi guru tidak melakukan penilaian ranah afektif dan psikomor disebabkan karena pengalaman mengajar yang dimiliki sehingga guru sudah memahami karakteristik siswa kelas III.

\section{PEMBAHASAN}

Penilaian dalam kurikulum 2013 yang mengacu pada Permendikbud Nomor 66 Tahun 2013 tentang Standar Penilaian Pendidikan. Standar penilaian bertjuan untuk menjamin: (1) perencanaan penilaian peserta didik sesuai dengan kompetensi yang akan dicapai dan berdasarkan prinsip-prinsip penilaian, (2) pelaksanaan penilaian peserta didik secara professional,terbuka. edukatif efektif, efisien dan sesuai dengan konteks sosial budaya, dan (3) pelaporan hasil penilaian peserta didik secara objektif, akuntabel, dan formatif. (Prastowo, 2018)

Penilaian autentik atau asesmen autentik merupakan kegiatan menilai peserta didik yang menekankan pada apa yang seharusnya dinilai, baik proses maupun hasil dengan berbagai instrument penilaian yang disesuaikan dengan tuntutan kompetensi yang ada di Standar Kompetensi (SK) atau Kompetensi Inti (KI) dan Kompetensi Dasar (KD) (Kunandar, 2014). Dalam hal ini dapat dipahami bahwa siswa dinilai 
kemampuannya dalam berbagai cara, tidak hanya melalui tes tertulis. Prinsip utama dalam penilaian autentik kurikulum 2013 tidak hanya menilai apa yang diketahui siswa, tetapi menilai apa yang dapat dilakukan siswa. Dalam hal ini penilaian juga mengutamakan penilaian kualitas hasil kerja siswa dalam menyelesaikan suatu tugas.

Standar penilaian ini disusun sebagai acuan penilaian bagi pendidik, satuan pendidikan dan pemerintah pada satuan pendidikan untuk jenjang pendidikan dasar dan menengah. Penilaian pendidikan sebagai proses mengumpulkan dan mengukur pencapaian hasil belajar peserta didik yang salah satunya mencakup penilaian autentik. Penilaian hasil belajar peserta didik yang mencakup kompetensi sikap, pengetahuan dan keterampilan yang dilakukan oleh guru secara berimbang sehingga dapat digunakan untuk menentukan posisi relative setiap peserta didik terhadap standar yang telah ditetapkan.

Menurut (Muslich, 2011) penilaian autentik ditunjukkan dengan proses penilaian yang mencakup sejumlah bukti yang menunjukkan pencapaian hasil belajar peserta didik. Penilaian ini dilakukan secara terpadu dalam kegiatan pembelajaran. Penilaian autentik dilakukan dengan berbagai cara seperti, portofolio, product, penugasan (project), kinerja (performance), dan tes tertulis. Jika mengacu pada Standar Kompetensi Lulusan (SKL) pada tingkat SD/MI dalam Permendikbud Nomor 54 Tahun 2013 bahwa mengenai kualifikasi kemampuan lulusan yang mencakup ranah sikap pengetahuan, dan keterampilan.

\section{Penerapan Penilaian Autentik Pada Tema Sumber Energi di MI Negeri 1 Yogyakarta}

Implementasi penilaian autentik dapat dilihat pada tiga hal, yakni: (1) perencanaan, yakni kualitas RPP, (2) pelaksanaan penilaian, dan (3) kedisiplinan guru dalam melakukan penilaian. Kualitas perencanaan penilaian dapat dilihat dari berbagai sisi namun yang paling utama adalah dilihat dari kualitas RPP. Hasil analisis yang telah dilakukan bahwa RPP yang digunakan guru menunjukkan bahwa ada butir-butir RPP yang sudah termasuk kategori baik yakni kesesuaian antara indikator dan kompetensi dasar. Langkah-langkah pembelajaran yang ada di RPP juga baik karena pembelajaran lebih berpusat kepada siswa. Sementara pada butir penilaian masih terdapat beberapa hal yang harus diperbaiki hal ini dikarenakan kurangnya variasi teknik penilaian yang digunakan untuk menilai kompetensi sikap dan keterampilan. Pada kompetensi pengetahuan menggunakan tes tertulis dalam bentuk tes lisan dan tertulis yang diterapkan guru di kelas.

Meskipun pada RPP sudah tercantum penilaian ranah afektif, kognitif dan psikomotor, pada implementasinya guru hanya melakukan penilaian ranah kognitif, hal ini sebagaimana yang tertuang pada hasil penelitian diatas bahwa yang melatarlebakangi guru tidak menggunakan instrument penilaian sikap dan keterampilan karena guru sudah memahami karakteristik anak kelas III SD/MI hal ini didasarkan oleh pengalaman mengajar kelas III yang sudah lama dijalani oleh guru.

Akan tetapi meskipun memiliki pengalaman mengajar yang lama, tentu tidak

MODELING, Volume 6, Nomor 2, September 2019 | 200 
menjami guru mampu secara optimal melakukan penilaian afektif tanpa adanya instrument penilaian yang digunakan sebagai pedoman dalam penelitian. Hal ini disebabkan karena masing-masing anak-anak memiliki karakteristik yang berbedaberbeda terutama anak usia SD/MI. Implementasi penilaian sikap atau ranah afektif pada jenjang usia dasar selain untuk menyempurnakan penilaian ranah kognitif juga sebagai penekanan kompetensi sikap harus benar-benar menjadi hal yang paling penting diperhatikan, hal ini bertujuan agar ketika peserta didik melanjutkan ke jenjang pendidikan yang lebih tinggi sudah memiliki fondasi sikap (sikap sosial dan spiritual) yang kuat dan dijenjang yang lebih tinggi tinggal memperdalam kompetensi pengetahuan dan keterampilannya.

Dalam hal ini tentu guru sebagai faktor utama dalam keberhasilan suatu pembelajaran harus memahami prinsip-prinsip yang berlaku yang telah ditetapkan oleh pemerintah. Dalam Standar Penilaian menurut Permendikbud RI No. 66 Tahun 2013 dalam buku (Prastowo, 2018) bahwa terdapat prinsip-prinsip penilaian, yaitu: (1) objektif, dalam hal ini berarti penilaian berbasis pada standar dan tidak dipengaruhi faktor subjektivitas penilai, (2) terpadu, berarti penilaian oleh pendidik dilakukan secara terencana, menyatu dengan kegiatan pembelajaran dan berkesinambungan, (3) ekonomis, berarti penilaian yang efisien dan efektif dalam perencanaan, pelaksanaan dan pelaporannya, (4) transparan, berarti prosedur penilaian, kriteria penilaian, dan dasar pengambilan keputusan dapat diakses semua pihak, (5) akuntabel, berarti penilaian dapat dipertanggung jawabkan kepada pihak internal sekolah maupun eksternal untuk aspek teknik, prosedur dan hasilnya, dan (6) edukatif, berarti mendidik dan memotivasi peserta didik dan guru.

Karakteristik penilaian hasil belajar pada tingkat SD/MI ranah afektif diantaranya siswa dituntut untuk memiliki prilaku yang mencerminkan sikap, beriman, berakhlak mulia, percaya diri dan bertanggung jawab dalam berinteraksi secara efektif dengan lingkungan sosial dan alam disekitar rumah, sekolah dan tempat bermain. Sedangkan pada ranah psikomotor yaitu kemampuan berfikir dan tindak yang efektif dan kreatif dalam ranah abstrak dan konkret (Kunandar, 2014).

Dalam penerapan penilaian autentik pada ranah sikap, guru dapat menerapkan beberapa penilaian diantaranya melalui observasi, penilaian diri, penilaian teman sejawat dan penilaian jurnal. Untuk penilaian ranah psikomotor dapat menggunakan penilaian kinerja yang menggunakan tes praktik, proyek dan penilaian portofolio. (Prastowo, 2018) Penilaian ini harus dilakukan oleh guru pada awal pembelajaran (penilaian input), selama pembelajaran (penilaian proses), dan setelah pembelajaran (penilaian output).

Selama proses observasi dilakukan tidak terlihat guru melakukan penilaian untuk ranah afektif dan psikomotor sejak awal hingga pembelajaran. Hanya saja yang sangat menonjol adalah guru memberikan pertanyaan-pertanyaan pancingan kepada siswa, guru memberikan tes lisan serta tes tertulis yang dalam hal ini dilakukan secara berkelompok oleh siswa. Hal ini ditunjukkan dengan tidak adanya guru intrumen penilaian yang telah dibuat ataupun dikembangan oleh guru. Apabila hal ini 
tidak segera diatasi maka akan memperburuk kualitas penilaian yang dilakukan oleh guru. Sejalan dengan permasalahan tersebut sebagaimana menurut pendapat (Chappuis, 2012) bahwa penilaian kelas yang dilakukan oleh guru akan berkhualitas jika: (1) tujuan penilaian jelas, (2) target penilaian jelas, (3) rancangan penilaian tepat dan (4) laporan penilaian tepat isi dan tepat sasaran.

Untuk itu, guna ketercapaian penerapan Kurikulum 2013 termasuk penerapan penilaian autentik, guru sebagai faktor utama yang berperan langsung bagi keberhasilan pembelajaran yang harus dicapai siswa harus memiliki sejumlah kemampuan yang harus dimiliki. Karena sebagus apapun pemerintah membuat sebuah kebijakan kurikulum jika sumber daya manusia nya tidak dapat memahaminya maka hal itu akan sia-sia. Adapun beberapa kompetensi yang harus dimiliki oleh guru menurut (Suparman, 2010) yaitu: (1) guru perlu menguasai bahan pembelajaran dengan baik, (2) guru harus terampil dalam merancang dan melaksanakan strategi pembelajaran, (3) guru harus mampu menggunakan sumber belajar yang tersedia, (4) guru harus mampu merancang dan menggunakan alat pengukuran yang baik sesuai dengan kompetensi dalam tujuan pembelajaran. Jadi, terdapat beberapa prinsip yang harus diperharikan oleh guru dalam menerapkan autentik asesmen dalam pembelajaran. Guru juga harus memiliki kompetensi yang dapat menunjang guna keberhasilan dan pencapaian hasil belajar peserta didik.

\section{PENUTUP}

Berdasarkan data dan pembahasan yang dilakukan, bahwa penerapan autentik asesmen pada siswa Kelas III C di MI Negeri1 Yogyakarta belum secara maksimal diterapkan. Hal ini guru hanya melakukan penilaian pada ranah kognitif melalui tes lisan dan tertulis, sedangkan pada ranah afektif dan psikomotor guru tidak melakukan penilaian. Hal ini berdasarkan fakta dilapangan dari hasil wawancara diperoleh keterangan bahwa latarbelakang guru yang sudah mengajar anak kelas III selama sepuluh tahun, sehingga guru sudah memahami karakteristik peserta didik kelas III.

\section{DAFTAR PUSTAKA}

Chappuis, S. d. (2012). An Introduction to Student-Involved Assessment for Learning. Boston: Addison Wesley.

Harsanto, R. (2007). Pengelolaan Kelas yang Dinamis. Yogyakarta: Kanisius.

Hosman, M. (2013). Pendekatan Saintifik dan Kontekstual Dalam Pembelajaran Abad Kunci Sukses Implementasi Kurikulum 2013. Bogor: Ghalia Indonesia.

Kunandar. (2014). Penilaian Autentik (Penilaian Hasil Belajar Peserta Didik Berdasarkan Kurikulum 2013). Jakarta: PT Raja Grafindo Persada.

Majid, A. (2014). Pembelajaran Tematik Terpadu. Bandung: PT Remaja Rosdakarya.

Muslich, M. (2011). Authentic Assessment: Penilaian Berbasis Kelas dan Kompetensi . Bandung: Refika Aditama.

Prastowo, A. (2018). Menyusun Rencana Pelaksanaan Pembelajaran (RPP) Tematik 
Wina Calista

Terpadu. Jakarta: Prenada Media Group.

Sugiyono. (2014). Metode Penelitian Kuantitatif, Kualitatif dan R\&D. Bandung: Alfabeta.

Sukmadinata, N. S. (2012). Pengembangan Kurikulum Teori dan Praktik. Bandung: Rosdakarya.

Suparman, A. (2010). Desain Intruksional Modern: Panduan Para Pengajar dan Inovator Pendidikan. Jakarta: Erlangga.

Uno, Hamzah B. (2012). Teori Motivasi dan Pengukurannya. Jakarta: PT Bumi Aksara. 